\title{
Changes of Alkaloid Composition During Curing in Three Isogenic Burley Tobaccos and Their $F_{1}$ Hybrids*
}

\author{
by B. I. Townes and S. J. Sheen \\ Department of Agronomy, University of Kentucky, Lexington, Kentucky, USA
}

\section{INTRODUCTION}

Alkaloids in tobacco, Nicotiana tabacum L., and related species have been extensively investigated because of their importance in smoking pleasure. Nicotine is the predominant alkaloid in tobacco leaves. The possible hazard of cigarette smoking to human health has resulted in a trend of decreasing nicotine content in cigarettes. The conversion of nicotine to nornicotine by a pair of dominant factors $(5,18)$ may be employed as a genetic means of reducing nicotine content in the leaf of commercial tobaccos. However, nornicotine contributes to unpleasant smoking taste. Genetic factors controlling alkaloid synthesis have been shown to be independent from those regulating nicotine-nornicotine conversion in tobacco $(8,15)$. Nicotine content in tobacco leaves may therefore be controlled by merely lowering total alkaloids. Valleau (15) has reported that total alkaloid content in tobacco might be governed by a rather simple genetic system. Legg et al. (7) recently reported that two nonlinked loci with additive gene action are responsible for determination of percent total alkaloids in certain burley crosses.

Nicotine is mainly synthesized in the root and translocated to the leaf of tobacco (3). The precursor of nicotine in tobacco roots remains an unanswered question. In studies of alkaloid biosynthesis in N. rustica, Tso and Jeffrey (14) and Tso (11) suggested that nornicotine is synthesized in the roots and may serve as a precursor of nicotine. In N. tabacum, nicotine conversion to nornicotine is believed to be a senescent phenomenon and takes place only in the leaf $(16,17$, 18). During flue-curing nicotine-nornicotine conversion occurred rapidly after 68 hours when the curing temperature was elevated above $56^{\circ} \mathrm{C}(16)$. The time of nicotine conversion and the change of alkaloid content during the course of air-curing have not been reported in the literature.

The present investigation was designed to study the effects of converter and alkaloid genotypes on the change of alkaloid composition in juvenile burley leaves and roots under simulated air-curing conditions.

\footnotetext{
* Journal Paper No. 70-3-96, Kentudky Agricultural Experiment Station, Lexington, Kentudky. Contribution from the Department of Agronomy; part of the dissertation submitted by the senior author in partial fulfillment of the requirements for the M. S. degree.

Received for publication: 14th July, 1970.
}

\section{MATERIALS AND METHODS}

Nicotiana tabacum cv. Burley 21 (a "normal" burley tobacco with respect to alkaloid content and a nonconverter, designated as high nicotine, $\mathrm{HN}$ ) and its isogenic lines for either low total alkaloids (LN) or nicotine conversion (C) were employed in this investigation. Plants were self-pollinated and crossed among the three genotypes. A total of nine entries, three parental lines and six $F_{1}$ progenies including the reciprocal ones were sown in 2-inch pots in October, 1967. After germination, young seedlings were potted into 2-inch pots, and later 20 juvenile plants of each entry were selected for uniformity and transplanted into 6-inch pots containing loam-sand mixture $(3: 1, v / v)$. The plants were grown in a greenhouse equipped with white-cool fluorescent lights for a 16-hour photoperiod. Greenhouse temperature was maintained at $27^{\circ} \mathrm{C}$ during the daytime and $18^{\circ} \mathrm{C}$ at night. The plants were irrigated with $200 \mathrm{ml}$ of half-strength Hoagland's (6) solution daily. At the six-leaf stage the apical buds were removed to induce physiological aging and alkaloid accumulation according to Griffith's small plant techniques (4). Two weeks later leaves of each entry were separately harvested and randomly divided into five groups, each of which consisted of 16 leaves. Similarly, the 20 root systems of each entry were equally divided into five groups. The leaves and roots were hung on sticks in an environmental chamber for curing. The aircuring simulation was performed in darkness with temperature at $24 \pm 1^{\circ} \mathrm{C}$ and relative humidity at $68 \pm 2 \%$ according to the method of Pogell et al. (9). The five sample groups of a given entry represent the following curing intervals; at harvest, 2 days, 4 days, 8 days, and 16 days. Plant materials collected at each curing interval were lyophilized, ground to pass 40-mesh screen, and stored in amber bottles at $-10^{\circ} \mathrm{C}$.

One gram of moisture-free powder was extracted with $80 \mathrm{ml}$ chloroform: methanol:saturated sodium hydroxide (30:19:1, v/v/v) in a Soxhlet apparatus for six hours. After cooling, the residue was removed by filtration and thoroughly washed with chloroform:methanol $(3: 2$, $\mathrm{v} / \mathrm{v})$ solvent. The combined filtrate was reduced to $2.5 \mathrm{ml}$ volume in vacuum at ambient temperatures. One hundred microliter portion was spotted on silica gel $\mathrm{G}$ thin-layer plate impregnated with $0.5 \mathrm{~N}$ potassium 
hydroxide. The plates were developed in an ascending manner with $250 \mathrm{ml}$ benzene: dioxane: $95 \%$ ethanol: ammonium hydroxide (10:8:1:1, v/v/v/v) and later placed in cyanogen bromide fumes. The principal alkaloids nicotine, nornicotine and anabasine were identified by co-chromatography with authentic compounds, color appearance in PABA-CNBr fume (12), and their fluorescent emissions under ultraviolet lights. In the present solvent system, nicotine, anabasine and nornicotine have $R_{\mathrm{f}}$ values $0.85,0.67$ and 0.47 , respectively. As shown by gas-liquid chromatographic analysis, the anabasine spot contains a substantial amount of anatabine (Dr. L. Bish, personal communication). However, the present study reports the quantity of both compounds as of anabasine. Individual spots were brushed off the plates, eluted with $5 \mathrm{ml} 0.1 \mathrm{~N} \mathrm{HCl}$ for one hour, and read on a Beckman DB-G spectrophotometer at $260 \mathrm{~nm}$ wavelength. The quantity of individual alkaloids is a mean of triplicate analyses. Total alkaloid content is the sum of the three principal compounds.

\section{RESULTS AND DISCUSSION}

Table I summarizes the quantity of individual and total alkaloids and nornicotine/nicotine ratios in the leaves of nine tobacco entries before and after aircuring. A lower amount of nicotine but higher nornicotine in green leaves of the $C$ line than the $H N$ strain indicate the possible occurrence of conversion during leaf growth. Genetic factors regulating nicotine to nornicotine conversion prior to curing have been found in $N$. tomentosiformis which is a progenitor of $N$. tabacum (17). Moreover, the content of total alkaloids in the $C$ line was only $64 \%$ of that of the HN strain at the same leaf age. It appears that these two genotypes differ not only for conversion but also for the amount of alkaloids. In the green tissue of the
LN line total alkaloids were only $20 \%$ the amount in the HN strain and yet, their nornicotine concentrations were comparable. Air-curing resulted in a five-fold increase of nornicotine in the $\mathrm{C}$ line as expected and some nornicotine accumulated in the $\mathrm{HN}$ and $\mathrm{LN}$ lines. After air-curing, the $\mathrm{HN}$ line lost $31 \%$ of the total alkaloids, whereas only a four percent decrease occurred in the $\mathrm{C}$. line. In contrast, alkaloid content increased $27 \%$ in the LN strain.

The alkaloid composition in the $F_{1}$ hybrids supports others' findings $(5,7,8,18)$ that nicotine conversion and total alkaloids are controlled by dominant gene or genes. The present results from the reciprocal crosses further indicate that there are no plasmogenes in determination of alkaloid metabolism in tobacco leaves. The total alkaloids in green leaves of the $\mathrm{C}$ and LN hybrids exceeded the level of either parent. This may be explained as a heterotic effect or a failure of early nicotine conversion or both. A similar nornicotine/ nicotine ratio for the green tissues of all six, $F_{1}$ hybrids suggests the absence of nicotine conversion during leaf growth in heterozygotes. The degree of conversion after air-curing as measured by the nornicotine/nicotine ratio revealed that the $F_{1}$ phenotype in the HN and $C$ crosses is comparable to that of the $C$ parent. In the case of the $L N$ and $C$ crosses this ratio fell into a nearly mid-parent value. Since the nicotine concentrations before or after air-curing in the four converter $F_{1}$ 's are in the same order of magnitude, a larger nornicotine content in the cured leaves of the HN crosses than the LN crosses requires explanation. If nornicotine is formed at the expense of nicotine during curing, the HN or LN germplasm may modify the converter factor in its efficiency of converting nicotine to nornicotine. This is in keeping with Burk and Jeffrey's (2) findings that in addition to a single dominant gene for nicotine conversion, a modifier gene had to be included to explain their results from

Table 1. Nicotine, nornicotine and anabasine content before and after air-curing in seedling leaves of three Burley 21 alkaloid isogenic lines and their $F_{\mathfrak{I}}$ hybrids*.

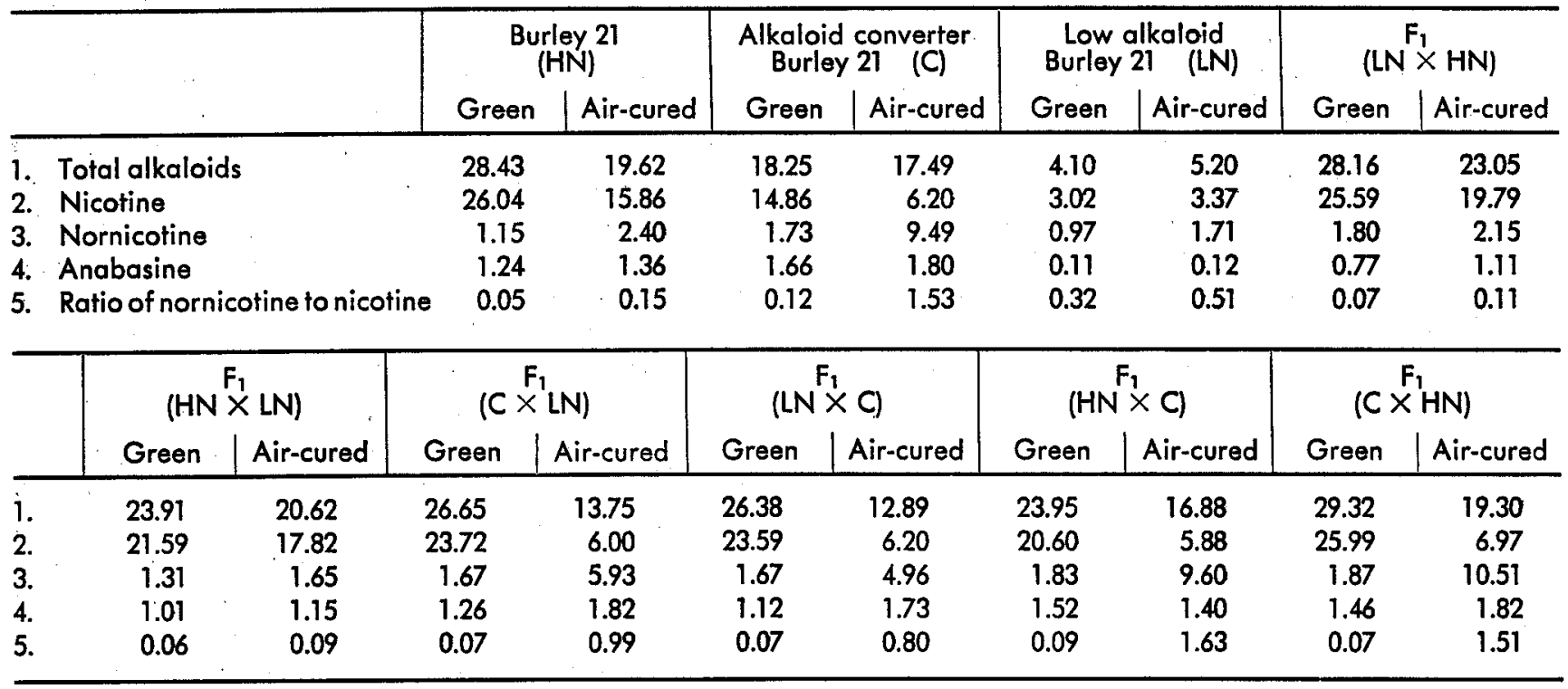

- Quantity is expressed in terms of $\mathrm{mg}$ nicotine equivalent/gm dry weight. 
Table 2. Nicotine, nornicotine and anabasine content before and after air-curing in seedling roots of three Burley 21 alkaloid isogenic lines and their $F_{1}$ hybrids*.

\begin{tabular}{|c|c|c|c|c|c|c|c|c|c|}
\hline & & \multicolumn{2}{|c|}{$\begin{array}{c}\text { Burley } 21 \\
(\mathrm{HN})\end{array}$} & \multicolumn{2}{|c|}{$\begin{array}{l}\text { Alkaloid converter } \\
\text { Burley } 21 \\
\begin{array}{ll}\text { (C) }\end{array}\end{array}$} & \multicolumn{2}{|c|}{$\begin{array}{l}\text { Low alkaloid } \\
\text { Burley } 21 \quad \text { (LN) }\end{array}$} & \multicolumn{2}{|c|}{$\left(\mathrm{LN}^{\mathrm{F}_{1}} \times \mathrm{HN}\right)$} \\
\hline & & Fresh & Air-cured & Fresh & Air-cured & Fresh & Air-cured & Fresh & Air-cured \\
\hline & Total alkaloids & 9.18 & 5.66 & 5.11 & 3.84 & 1.92 & 1.53 & 7.09 & 6.01 \\
\hline 2. & Nicotine & 6.27 & 4.44 & 3.89 & 2.71 & 1.42 & 1.00 & 4.93 & 4.37 \\
\hline 3. & Nornicotine & 2.08 & 1.12 & 1.09 & 1.07 & 0.30 & 0.50 & 1.36 & 1.00 \\
\hline 4. & Anabasine & 0.83 & 0.10 & 0.13 & 0.06 & 0.20 & 0.03 & 0.80 & 0.64 \\
\hline 5. & Ratio of nornicotine to nicotine & 0.33 & 0.25 & 0.28 & 0.39 & 0.21 & 0.50 & 0.28 & 0.23 \\
\hline
\end{tabular}

\begin{tabular}{|c|c|c|c|c|c|c|c|c|c|c|}
\hline & \multicolumn{2}{|c|}{$\left(H N \stackrel{F_{1}}{\times} L N\right)$} & \multicolumn{2}{|c|}{$\left(C \stackrel{F_{1}}{\times} \mathrm{LN}\right)$} & \multicolumn{2}{|c|}{$\left(L^{F_{1}} \times C\right)$} & \multicolumn{2}{|c|}{$\left(H N^{F_{1}} \times C\right)$} & \multicolumn{2}{|c|}{$\left(C \stackrel{F_{1}}{\times} \mathrm{HN}\right)$} \\
\hline & Fresh & Air-cured & Fresh & Air-cured & Fresh & Air-cured & Fresh & Air-cured & Fresh & Air-cured \\
\hline 1. & 5.43 & 4.53 & 7.38 & 1.70 & 5.94 & 1.93 & 8.15 & 2.65 & 5.12 & 3.70 \\
\hline 2. & 3.00 & 3.29 & 5.70 & 1.08 & 4.41 & 1.18 & 5.79 & 2.17 & 3.24 & 2.55 \\
\hline 3. & 1.05 & 1.00 & 1.49 & 0.51 & 1.32 & 0.64 & 1.76 & 0.74 & 1.14 & 0.90 \\
\hline 4. & 0.72 & 0.65 & 0.19 & 0.11 & 0.21 & 0.11 & 0.60 & 0.30 & 0.74 & 0.25 \\
\hline 5. & 0.35 & 0.30 & 0.26 & 0.47 & 0.30 & 0.54 & 0.30 & 0.34 & 0.35 & 0.35 \\
\hline
\end{tabular}

- Quantity is expressed in terms of $\mathrm{mg}$ nicotine equivalent/gm dry weight.

segregating populations. Forty-nine percent of nicotine loss during curing was transformed to nornicotine in the $\mathrm{HN}$ and $\mathrm{C}$ crosses, while there was only $22 \%$ in the $\mathrm{LN}$ and $\mathrm{C}$ crosses. Since catabolism prevails during air-curing, the LN strain may therefore possess a different genetic system for alkaloid decomposition and/ or interconversion. Anabasine content in tobacco leaves appeared to be highest in the $C$ line and lowest in the LN strain. Similarly, the $F_{1}$ plants derived from the $C$ line showed higher anabasine concentration than that of the $\mathrm{HN}$ and LN crosses. Air-curing resulted in a slight increase in anabasine content in most cases.

On a dry weight basis, fresh root tissues contained much less alkaloids than the aerial portion of plants; however, nicotine, nornicotine and anabasine were still in measurable quantities (Table 2). The individual and total alkaloid quantity in roots of the three isogenic burley strains corresponds to the same order as in their leaves. A relatively high concentration of nornicotine in fresh roots is reflected by a high nornicotine/ nicotine ratio in all cases except the $\mathrm{LN}$ strain. In contrast to the leaf, the air-curing process resulted in a decrease of nornicotine in the root except in the LN strain. The $F_{1}$ 's of reciprocal crosses showed a similar pattern of change in alkaloid composition before and after curing. The $\mathrm{HN}$ and $\mathrm{LN}$ hybrids did not exhibit any drastic change in nicotine and nornicotine contents due to curing, whereas the other four $F_{1}$ 's involving the $C$ line as parent decreased these alkaloids considerably. In the $C$ and $L N$ hybrids, nicotine content decreased more than nornicotine during the curing period and consequently, a high nornicotine/nicotine ratio comparable to that of the LN parent was obtained. It suggests that the rate of nicotine decomposition in tobacco roots may be a determinant factor for alkaloid accumulation in the leaves.

The change of nicotine and nornicotine concentrations during the course of air-curing may reveal the precursor-product relationship. The patterns of this relationship expressed in terms of nornicotine/nicotine ratio in the leaves and roots are shown in Figs. 1 and 2 , respectively. An increase in ratio can be attributed to a net gain of nornicotine, a loss of nicotine, or both. A slight change of the ratio for the leaves of HN, LN and their $F_{1}$ hybrids during curing is expected because of the absence of the converter factor. Significant changes were noticeable in the $C$ line and its progenies. If nicotine conversion is a one-step reaction involving transmethylation (1) or oxidative demethylation (10), one would anticipate a direct relationship between nicotine loss and nornicotine gain at a given curing interval. The present results revealed that nicotine decomposition occurred in the early curing stages and nornicotine increase began only at the $4^{\text {th }}$ curing day. The accumulation of nornicotine became much more prominent after the 8 th day as reflected by a steady increase of nornicotine/nicotine ratio. Out of phase for nicotine decomposition and nornicotine accumulation suggests that there is no single one-step conversion between these two alkaloids. Since all alkaloids are metabolically active and interconvertible in the general metabolic pool $(11,13)$, unknown metabolites derived from nicotine decomposition may be involved to bridge the time lag for nornicotine formation. These intermediate nitrogen-containing compounds, if any, are apparently not detected by the present analytical method. In roots, a relatively high nornicotine concentration gave rise to a high initial ratio of nornicotine to nicotine. Air-curing caused less than one-fold increase in ratio for the $C$ strains, suggesting that the converter factor has an extremely low expressivity in root tissues. One interesting phenomenon was a rapid loss of nicotine from $1.42 \mathrm{mg} / \mathrm{g}$ to $0.29 \mathrm{mg} / \mathrm{g}$ at the beginning of curing in the LN line, while nornicotine content altered only slightly from $0.30 \mathrm{mg} / \mathrm{g}$ to $0.40 \mathrm{mg} / \mathrm{g}$. This shift of proportion resulted in a six-fold increase in the nornicotine/nicotine ratio at the $4^{\text {th }}$ curing day. Sixtythree percent of nicotine loss was later recovered, but 
Figure 1. Changes of the nornicotine/nicotine ratio during air-curing in the seedling leaves of three Burley 21 alkaloid isogenic lines and their $F_{1}$ hybrids.

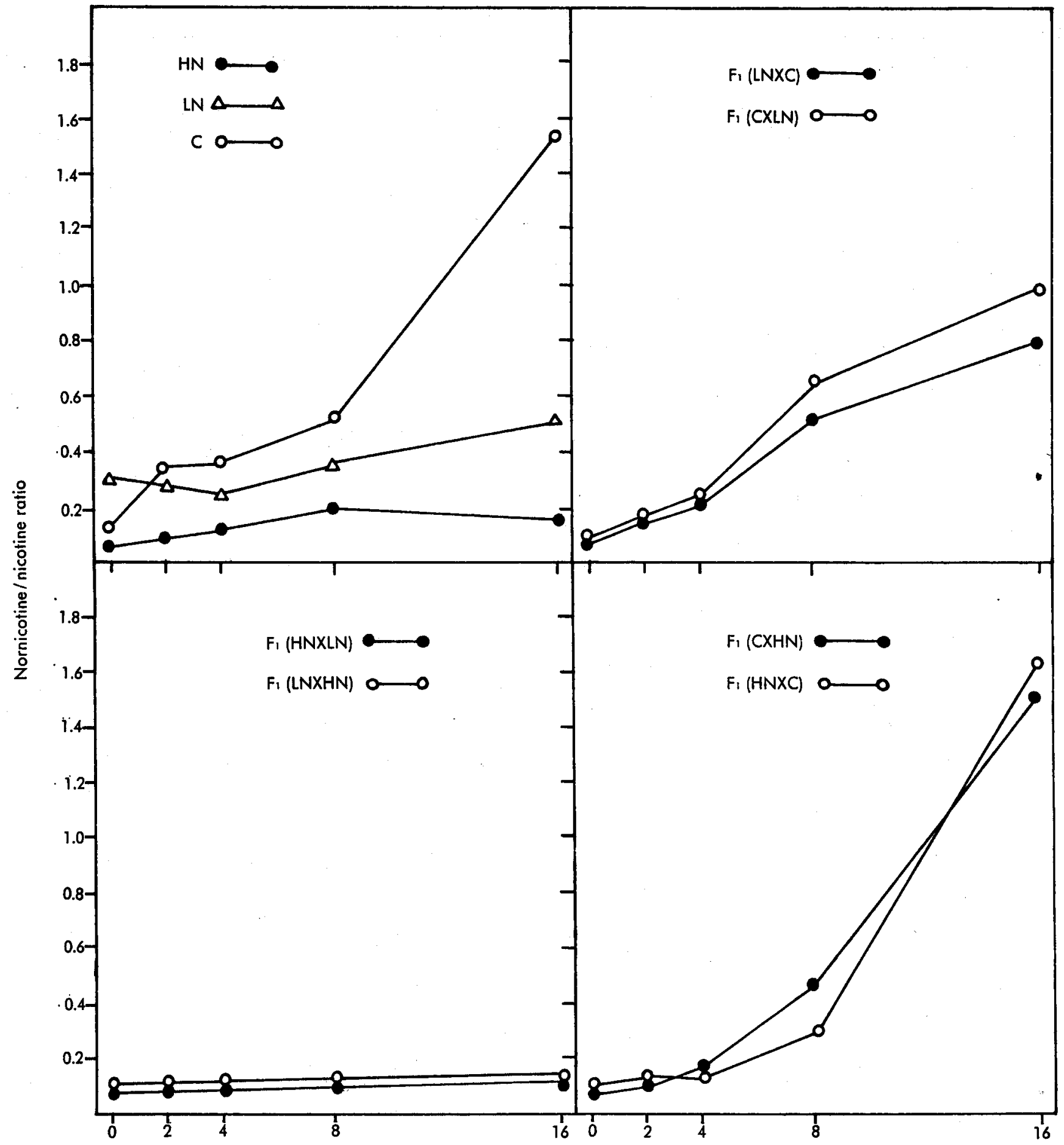

Air-curing days

nornicotine content maintained at a steady level. As a result, the ratio of the two alkaloids dropped by the end of curing. This phenomenon occurred to a lesser extent in the roots of the HN and LN hybrids. In the $F_{1}$ 's of the $L N$ and $C$ crosses the nicotine increase was not noticed at the last phase of curing. Whether this is due to the influence of converter factor or other genic interactions can only be answered by future experiments.

The parallel comparison of alkaloid composition in leaves and roots reported herein offers further understanding of the time, site, and magnitude of gene function and genic interaction in relation to the accumulation of alkaloids in tobacco. The genetic mechanism regulating nicotine metabolism in roots of the LN line likely bears impact on lowering the total alkaloids in its leaves. Interestingly enough, this metabolic phenomenon did not occur in the leaf possessing the same genotype. Although curing decreased nornicotine content in the root, the increase of this alkaloid in the leaf suggests in situ synthesis. Nevertheless, the amount of increase is much greater in the converter line and its progenies than the non-converters. A considerable amount of confusion exists in the literature as to the interpretation of the genetic system of nico- 
figure 2. Changes of the nornicotine/nicotine ratio during air-curing in the seedling roots of three Burley 21 alkaloid isogenic lines and their $F_{1}$ hybrids.

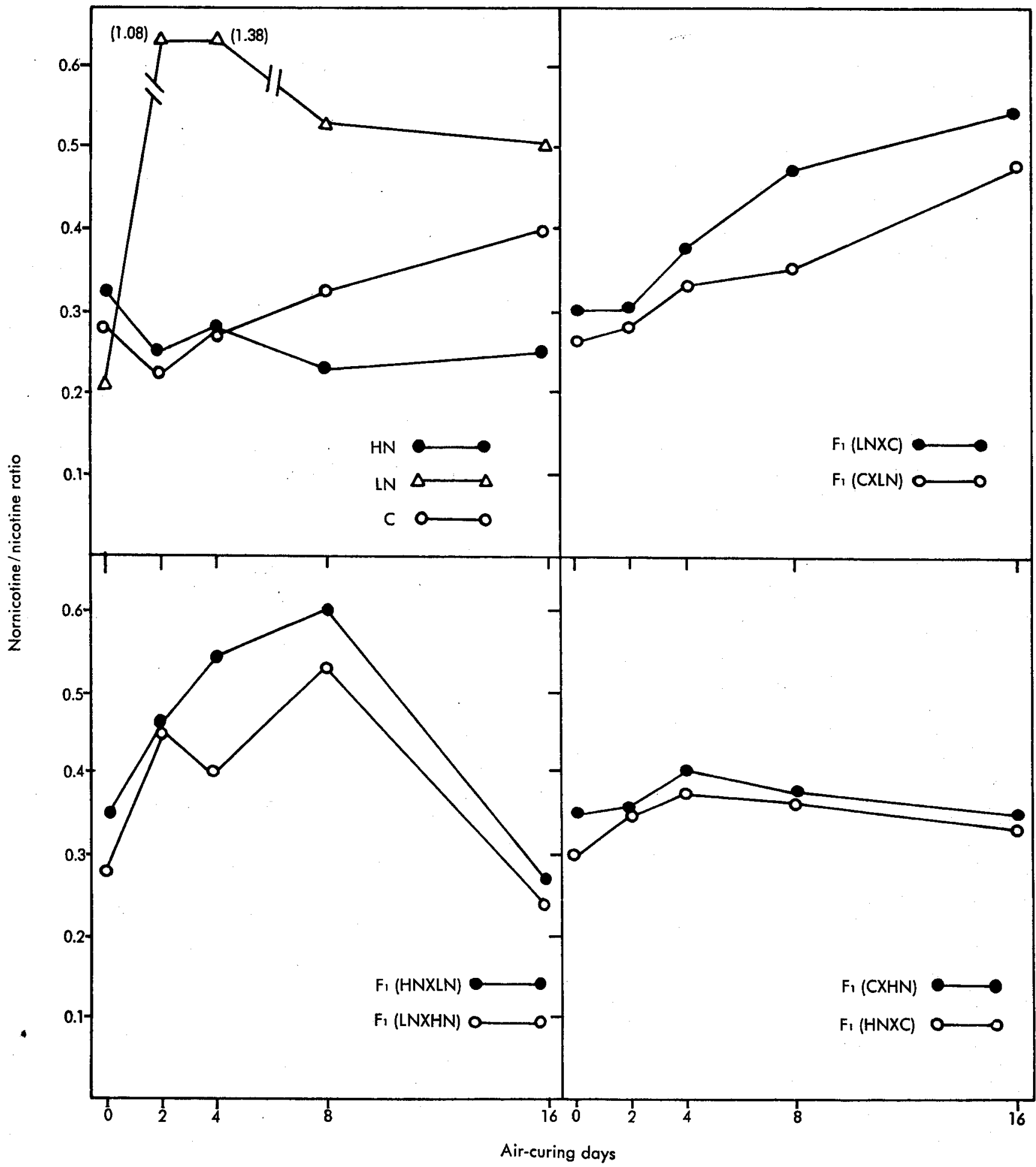

tine. conversion. One point of confusion stems from the difficulty in separating low level converters from nonconverters. As a matter of fact, the physiological role of the converter gene is still unknown. Whether the converter gene controls the rate of nicotine demethylation, nornicotine degradation, nornicotine synthesis, or others needs to be answered prior to a successful genetic control of alkaloids in tobacco. If the converter gene enhances the turn-over rate of nicotine metabolism in the leaf, a further lowering of the total alkaloids may be possible by recombination of the LN and C genotypes.

\section{SUMMARY}

Quantitative changes of nicotine, nornicotine, anabasine (including anatabine), and total alkaloids in the juvenile leaves and roots of Nicotiana tabacum cv. Burley $2 I$ (HN) and its isogenic lines selected for nicotine conversion (C), and low total alkaloids (LN) were studied during air-curing simulation. In the leaf, the $C$ line contained less total alkaloids but more nornicotine than the $\mathrm{HN}$ line, suggesting that some may have been converted to nornicotine during leaf growth. The conversion phenomenon was not observed in the root. The 
root tissues of the LN line showed a high rate of nicotine decomposition at the inception of curing. On the basis of $F_{1}$ results, both total alkaloids and nicotine conversion are governed by dominant factors. An intermediate nornicotine/nicotine ratio for the cured leaves of the $\mathrm{LN}$ and $\mathrm{C}$ hybrids indicated the presence of converter modifiers in the $\mathrm{LN}$ line. In the $\mathrm{C}$ line and its hybrids the decrease of nicotine content mainly occurred at the beginning of curing, whereas the nornicotine increase appeared after the eighth day of curing. The amount of anabasine was increased in the leaf but was decreased in the roots by curing.

\section{ZUSAMMENFASSUNG}

Die quantitativen Veränderungen von Nikotin, Nornikotin, Anabasin (einschließlich Anatabin) und von den Gesamtalkaloiden in den jugendlichen Blättern und Wurzeln von Nicotiana tabacum cv. Burley 21 (HN) und dessen isogenen Linien, die im Hinblick auf die Nikotinumwandlung (C) und auf einen geringen $\mathrm{Ge}-$ samtgehalt an Alkaloiden (LN) ausgewählt worden waren, wurden im Verlauf einer simulierten Lufttrocknung untersucht. Die Blätter der C-Linie hatten einen geringeren Gehalt an Gesamtalkaloiden, enthielten aber mehr Nornikotin als die HN-Linie, was darauf hinweist, daß sich ein Teil der Gesamtalkaloide während des Blattwachstums zu Nornikotin umgewandelt haben könnte. In den Wurzeln wurde dieses Umwandlungsphänomen nicht beobachtet. Die Wurzelgewebe der LN-Linie zeigten einen starken Nikotinabbau zu Beginn des Trocknungsprozesses. Ergebnisse von Untersuchungen an der $F_{1}$-Generation zeigen, daß sowohl der Gehalt an Gesamtalkaloiden als auch der Nikotinabbau durch Dominanz-Faktoren beherrscht werden. Ein intermediäres Nornikotin/Nikotin-Verhältnis bei den getrockneten Blättern der LN- und C-Hybriden wies auf das Vorkommen von modifizierenden Faktoren bei der LNLinie hin. Bei der C-Linie und deren Hybriden trat die Abnahme des Nikotingehaltes vornehmlich zu Beginn des Trocknungsvorganges auf, während sich die $\mathrm{Zu}$ nahme des Nornikotins erst nach dem achten Trocknungstag zeigte. Durch die Trocknung wurde der Gehalt an Anabasin in den Blättern erhöht, in den Wurzeln dagegen vermindert.

\section{RESUME}

Dans une expérience simulant $l^{\prime}$ «air-curing", on a étudié la variation quantitative de la teneur en nicotine, nornicotine, anabasine ( $y$ compris l'anatabine), des alcaloïdes totaux dans les feuilles juvéniles et les racines de Nicotiana tabacum cv. Burley 21 (HN) et de sa filiation isogénique sélectionnée pour la conversion de la nicotine (C), et des alcaloïdes totaux mineurs (LN). Dans les feuilles, la filiation $C$ contient moins d'alcaloïdes totaux. mais davantage de nornicotine que la filiation $\mathrm{HN}$. Ceci suggère qu'une partie des alcaloïdes auraient pu être convertis en nornicotine pendant la croissance des feuil- les. Ce phénomène de conversion n'a pu être observé dans les racines. Dans les tissus des racines de la filiation $\mathrm{LN}$, on trouve une proportion importante de nicotine décomposée au stade initial du séchage. D'après les résultats de la première génération, la conversion de la nicotine et des alcaloïdes totaux est déterminées par des facteurs dominants. Une proportion intermédiaire nornicotine/nicotine dans les feuilles séchées des hybrides $\mathrm{LN}$ et $\mathrm{C}$ indique la présence de modificateurs de conversion dans la filiation LN. Dans la filiation $C$ et ses hybrides, la diminution de la teneur en nicotine apparait surtout au début du séchage, alors que l'augmentation de la nornicotine se manifeste après le huitième jour de séchage. Durant le séchage, la teneur en anabasine augmente dans les feuilles, et diminue dans les racines.

\section{REFERENCES}

1. Bose, B. C., De, H. N., and Sultan, M.: India Jour. Med. Res. 44 (1956) 91.

2. Burk, L. G., and Jeffrey, R. N.: Tob. Sci. 2 (1958) 139 .

3. Dawson, R. F.: Amer. Jour. Bot. 29 (1942) 66.

4. Griffith, R. B.: Tob. Chem. Res. Conf. 13th, Lexington, Ky., Paper No. 25 (1959).

5. Griffith, R. B., Valleau, W. D., and Stokes, G. W.: Science I2I (1955) 343.

6. Hoagland, D. R., and Arnon, D. I.: Calif. Agri. Exp. Sta. Cir. 347 (1950) I.

7. Legg, P. D., Chaplin, J. F., and Collins, G. B.: Jour. of Hered. 60 (1969) 213.

8. Mann, T. J., and Weybrew, J. A.: Tob. Sci. 2 (1958) 29.

9. Pogell, B. M., Moseley, J. M., Likes, C. J., and Koenig, D. F.: Tob. Sci. I (1957) 138.

10. Stepka, W., and Dewey, L. J.: Plant Physiol. 36 (I961) 592.

11. Tso, T. C.: Bot. Bull. Acad. Sinica 4 (1963) 75.

12. Tso, T. C., and Jeffrey, R. N.: Arch. Biochem. Biophys. 43 (1953) 269.

13. Tso, T. C., and Jeffrey, R. N.: Arch. Biochem. Biophys. 92 (1961) 253.

14. Tso, T. C., and Jeffrey, R. N.: Arch. Biochem. Biophys. 97 (1962) 97.

15. Valleau, W. D.: Jour. Agric. Res. 78 (1949) I71.

16. Wada, E.: Tob. Sci. I (1957) 118.

17. Wernsman, E. A., and Matzinger, D. F.: Tob. Sci. 12 (1968) 226.

18. Weybrew, J. A., Mann, T, J., and Moore, E. L.: Tob. Sci. 4 (1960) 190.

\section{Acknowledgement}

We wish to gratefully acknowledge the helpful comments and suggestions of Dr. T. C. Tso (U.S.D.A.) and Dr. L. P. Bush (University of Kentucky).

The authors' address:

Department of Agronomy, University of Kentucky, Lexington, Kentucky, 40506, USA. 